\title{
Autoantibody to the C3b/C4b Receptor and Absence of this Receptor from Erythrocytes of a Patient with Systemic Lupus Erythematosus
}

James G. Wilson, Richard M. Jack, Winnie W. Wong, Peter H. Schur, and Douglas T. Fearon

Department of Medicine, Harvard Medical School, and Department of Rheumatology and Immunology, Brigham and Women's Hospital, Boston, Massachusetts 02115

\section{Abstract}

A 29-yr-old woman with systemic lupus erythematosus (SLE) was found to have no detectable $\mathrm{C} 3 \mathrm{~b} / \mathrm{C} 4 \mathrm{~b}$ receptors (CR1) on her erythrocytes (E) when they were assayed by the binding of rabbit polyclonal and murine monoclonal (Yz-1) anti-CR1. Analysis by two-color fluorescent flow cytometry of CR1 expression on the patient's B lymphocytes that had been stained indirectly with monoclonal anti-B1 and rabbit $F\left(\mathbf{a b}^{\prime}\right)_{2}$ anti-CR1 also revealed a marked deficiency of CR1. Total cellular CR1 of neutrophils, assessed by a sandwich radioimmunoassay, was about half that of neutrophils from normal individuals. Because her E had expressed 173 sites/cell 2 yr before, the CR1 deficiency was considered to be acquired and a possible mechanism was sought.

Autoantibody to CR1 was measured by a radioimmunoassay in which serum or its fractions were incubated in microtiter wells that had been coated with purified CR1, and binding of immunoglobulin to the wells was quantitated with ${ }^{125}$ I-labeled goat IgG antihuman $F\left(\mathbf{a b}^{\prime}\right)_{2}$. The CR1-specific binding of immunoglobulin from the patient's serum was $19.1 \mathrm{ng} /$ well of the detecting antibody when hër $E$ had eight CR1 sites per cell; that of 28 healthy donors was $1.3 \pm 0.5 \mathrm{ng} /$ well (mean \pm SEM), and that of 34 additional patients with SLE was $0.5 \pm 0.3 \mathrm{ng} /$ well. The activity was present also in purified IgG and its $F\left(a^{\prime}\right)_{2}$ fragment, indicating that the binding of serum immunoglobulin to CR1 was not mediated by $\mathrm{C} 3$ fragments. The specificity of the patient's IgG for CR1 was confirmed when pretreatment of the CR1-coated wells with affinity-purified rabbit $\mathrm{F}\left(\mathrm{ab}^{\prime}\right)_{2}$ anti-CR1 was shown to inhibit by $68 \%$ the binding of the IgG. The autoantibody also interacted with CR1 in cell membranes, as assessed by its capacity to inhibit the binding of indirectly fluoresceinated $\mathrm{Yz}-1$ to neutrophils, and, when combined with goat IgG antihuman $F\left(a^{\prime}\right)_{2}$, to diminish the binding of dimeric C3b to normal $\mathbf{E}$.

During the period of the marked deficiency of CR1 the patient experienced an exacerbation of disease activity which was treated with prednisone. Clinical improvement was accompanied by a decrease in the serum concentration of anti-CR1 to levels present $2 \mathrm{yr}$ earlier, and an increase of CR1 to 170 sites/E. The temporal association between high titers of an autoantibody to CR1, absence of CR1 from $E$, and heightened activity of SLE suggest that the former may have had a role in the other manifestations of the patient's disease.

Address reprint requests to Dr. Wilson, 617 Seeley G. Mudd Building, 250 Longwood Avenue, Boston, MA 02115.

Received for publication 26 December 1984.

J. Clin. Invest.

(c) The American Society for Clinical Investigation, Inc. 0021-9738/85/07/0182/09 \$1.00

Volume 76, July 1985, 182-190

\section{Introduction}

Systemic lupus erythematosus (SLE) ${ }^{1}$ is an autoimmune disease characterized by the presence of autoantibodies to multiple antigens. Among these are antibodies to the nuclear antigens, single- and double-stranded DNA (dsDNA), ribonucleoproteins and histones (1), cytoskeletal proteins $(2,3)$, cell surface constituents such as Ia (4), $\beta$-2 microglobulin (5), and asialo$\mathrm{GM}_{1}(6)$, and plasma proteins such as immunoglobulin and the classical pathway C3 convertase, C4b,2a (7-9). The biologic effects of some autoantibodies are direct, such as the prolongation of the half-life of $\mathrm{C} 4 \mathrm{~b}, 2 \mathrm{a}$ by its autoantibody, whereas the pathophysiologic effects of other antibodies, such as those directed to DNA, may be mediated indirectly by the formation of immune complexes (10).

Patients with SLE have recently been recognized as having a relative deficiency of the $\mathrm{C} 3 \mathrm{~b} / \mathrm{C} 4 \mathrm{~b}$ receptor $(\mathrm{CR} 1)$ on their erythrocytes (E) (11-16) that impairs the capacity of these cells to bind DNA-anti-dsDNA complexes in vitro (17). In addition, patients with proliferative glomerulonephritis of SLE have no detectable CRI on podocytes in affected glomeruli, although individuals with other types of endocapillary proliferative glomerulonephritis have apparently normal expression of CR 1 on their podocytes $(18,19)$. Two general mechanisms have been shown to account for the abnormality on E: a primary deficiency caused by inheritance of an allele(s) associated with low $C R 1$ number $(13,16)$, and a secondary deficiency caused by accelerated catabolism of CR 1 in association with complement activation at the cell surface (15). The deficiency of CR 1 on $\mathrm{E}$ may contribute to the elevated plasma levels of immune complexes that occur in SLE because the capacity of E to clear complexes from the circulation depends on their expression of this receptor (20).

In the present study another possible mechanism for an acquired deficiency of CR1 is described in which a patient with SLE was found to have autoantibodies directed to this protein. A temporal association in this patient between heightened activity of disease, absence of CR1 from E, and high titers of auto-anti-CR 1 suggests that the latter may have had a role in the clinical manifestations of her disease.

1. Abbreviations used in this paper: ANA, antinuclear antibody; B1biotin, murine monoclonal IgG, directed to the B1 antigen of B lymphocytes, that has been conjugated with biotin; CR1, the human $\mathrm{C} 3 \mathrm{~b} / \mathrm{C} 4 \mathrm{~b}$ receptor; dsDNA, double-stranded DNA; E, erythrocyte(s); FITC, fluorescein isothiocyanate; FITC-GaM, FITC-conjugated goat IgG anti-mouse IgG; FITC-GaR, FITC-conjugated goat $\mathrm{F}\left(\mathrm{ab}^{\prime}\right)_{2}$ antirabbit $\mathrm{F}\left(\mathrm{ab}^{\prime}\right)_{2}$; HBSS-BSA, HBSS containing $0.1 \%$ BSA; HBSS- $1 \%$ BSA, HBSS containing 1\% BSA; NHS, normal human serum; RaCR1, affinity-purified rabbit $F\left(a b^{\prime}\right)_{2}$ directed to $C R 1$; SDS-PAGE, sodium dodecyl sulfate-polyacrylamide gel electrophoresis; SLE, systemic lupus erythematosus; XRITC, rhodamine 600 . 


\section{Methods}

Antibodies. Affinity-purified rabbit IgG and $\mathrm{F}\left(\mathrm{ab}^{\prime}\right)_{2}$ antihuman $\mathrm{CR} 1$ $(\mathrm{RaCR} 1)$ were prepared as described $(13,21)$. The $\mathrm{F}\left(\mathrm{ab}^{\prime}\right)_{2}$ fragment was radiolabeled to a specific activity of $1.2 \times 10^{6} \mathrm{cpm} / \mu \mathrm{g}(22)$. Murine monoclonal Yz-1 IgG anti-CR1 (23) was purified from ascites by precipitation with $50 \%$ saturated ammonium sulfate and chromatography on DEAE Sephacel (Pharmacia Fine Chemicals, Piscataway, $\mathrm{NJ}$ ). Fab fragments were produced by papain digestion of purified Yz1 (24). Yz-1 IgG and Fab were radiolabeled with ${ }^{125}$ I (Amersham Corp., Arlington Heights, IL) to specific activities of 1.8-3.1 $\times 10^{6}$ $\mathrm{cpm} / \mu \mathrm{g}(22)$.

Biotin-conjugated monoclonal anti-B1 (B1-biotin) (Coulter Immunology, Hialeah, FL), which recognizes a $35,000 M_{\mathrm{r}}$ antigen present on the surface of B lymphocytes (25), human isotype- and light chainspecific affinity-purified goat IgG (Southern Biotechnology Associates, Birmingham, AL), fluorescein isothiocyanate (FITC)-conjugated goat $\mathrm{F}\left(\mathrm{ab}^{\prime}\right)_{2}$ antirabbit $\mathrm{F}\left(\mathrm{ab}^{\prime}\right)_{2}$ (FITC-GaR; Cappel Laboratories, West Chester, PA), and FITC-conjugated goat IgG antimouse IgG (FITC-GaM) (Southern Biotechnology Associates) were obtained. The isotype- and light chain-specific goat antihuman immunoglobulins were radiolabeled with ${ }^{125} \mathrm{I}$ to specific activities of $0.9-1.4 \times 10^{6} \mathrm{cpm} / \mu \mathrm{g}(22)$. The FITC-GaR was preabsorbed with human IgG that had been coupled to $\mathrm{CNBr}$-activated Sepharose (Sigma Chemical Co., St. Louis, MO).

Purification of CR1. CR1 was purified as described (26, 27). Purified CRI was radiolabeled using the Bolton-Hunter reagent (New England Nuclear, Boston, MA) and analyzed by electrophoresis on a gradient gel of 3 to $10 \%$ acrylamide in the presence of sodium dedecyl sulfate (SDS-PAGE) (28) followed by autoradiography. Some studies used CRI of similar purity that had been prepared by a modified procedure using affinity chromatography on Yz-1-Sepharose.

Quantitation of CRI. The number of CR1 on E was determined by incubation of washed $\mathrm{E}$ for $1 \mathrm{~h}$ at $22^{\circ} \mathrm{C}$ with incremental concentrations of either ${ }^{125} \mathrm{I}-\mathrm{Yz}-1$ (from 0.03 to $1.0 \mu \mathrm{g} / \mathrm{ml}$ ) or ${ }^{125} \mathrm{I}-\mathrm{RaCR} 1$ (from 0.16 to $5.13 \mu \mathrm{g} / \mathrm{ml}$ ) followed by centrifugation of $\mathrm{E}$ through cushions of dibutylphthalate (Eastman Kodak Co., Rochester, NY) (13). The preparation and binding of ${ }^{125} \mathrm{I}$-dimeric $\mathrm{C} 3 \mathrm{~b}$ to $\mathrm{E}$ was performed as described (13). Erythrocyte CR1 was also analyzed by immunoblotting as described $(29,30)$. Total cellular CR1 in detergent lysates of purified neutrophils (31) was measured by a modification of the sandwich protocol of Unkeless and Healy $(29,32)$.

For quantitation of CR1 on B lymphocytes by cytofluorography, $4 \times 10^{6}$ mononuclear leukocytes were incubated for $30 \mathrm{~min}$ at $0^{\circ} \mathrm{C}$ with $15 \mu \mathrm{g} / \mathrm{ml}$ of either RaCR1 or nonimmune rabbit $\mathrm{F}\left(\mathrm{ab}^{\prime}\right)_{2}$ in 0.065 $\mathrm{ml}$ Hanks' balanced salt solution (M. A. Bioproducts, Walkersville, MD) containing $0.1 \%$ bovine serum albumin (Miles Scientific, Naperville, IL) (HBSS-BSA) and $40 \%$ heat-inactivated pooled normal human serum (NHS). The cells were washed in $2.5 \mathrm{ml} \mathrm{HBSS}-\mathrm{BSA}$ and incubated at $4^{\circ} \mathrm{C}$ for $30 \mathrm{~min}$ with $125 \mu \mathrm{g} / \mathrm{ml}$ FITC-GaR in HBSSBSA containing NHS. The cells were washed, resuspended in HBSSBSA containing B1-biotin, and incubated for $30 \mathrm{~min}$ at $0^{\circ} \mathrm{C}$. After the cells were washed they were incubated for $20 \mathrm{~min}$ at $0^{\circ} \mathrm{C}$ with $60 \mu \mathrm{g} /$ $\mathrm{ml} \mathrm{XRITC} \mathrm{(rhodamine} \mathrm{600)-conjugated} \mathrm{avidin} \mathrm{(Vector} \mathrm{Laboratories,}$ Burlingame, CA). After a final wash, the cells were fixed in $0.1 \mathrm{ml} 2 \%$ paraformaldehyde and held at $4^{\circ} \mathrm{C}$ in the dark until they were evaluated by flow cytometry.

Neutrophils were stained with Yz-1 by incubation of $4 \times 10^{6}$ cells in $0.05 \mathrm{ml} \mathrm{HBSS}-B S A$ with $5 \mu \mathrm{g} / \mathrm{ml} \mathrm{Yz-1}$ or UPC-10, an irrelevant, anti-levan monoclonal antibody (Litton Bionetics, Charleston, SC), for $30 \mathrm{~min}$ at $0^{\circ} \mathrm{C}$. The cells were washed and incubated for $30 \mathrm{~min}$ with $15 \mu \mathrm{g} / \mathrm{ml}$ FITC-GaM in the presence of $33 \%$ NHS, washed again, and fixed in paraformaldehyde and held at $4^{\circ} \mathrm{C}$ until analysis by flow cytometry.

Immunofluorescent staining was analyzed with a Cytofluorograf system 50-H (Ortho Diagnostic Systems, Westwood, MA) equipped with an argon laser operated at $488 \mathrm{~nm}$ and $250 \mathrm{~mW}$ and a krypton laser operated at $568.2 \mathrm{~nm}$ and $200 \mathrm{~mW}$, and interfaced with a model
2150 Data Handler (Ortho Diagnostic Systems). The relative fluorescence intensity was standardized from day to day by adjustment of the gains to yield a constant mean channel of fluorescence for stock suspensions of calf thymocyte nuclei that had been conjugated with FITC or XRITC, respectively (Ortho Diagnostic Systems).

Purification of human IgG and preparation of $F\left(a b^{\prime}\right)_{2}$. IgG was purified from human serum by precipitation in 50\% saturated ammonium sulfate and subsequent dialysis against $0.0175 \mathrm{mM}$ sodium phosphate, $\mathrm{pH} 6.3$, and application to a column of DE-52 cellulose (Whatman Chemical Separation Inc., Clifton, NJ) equilibrated in this buffer (24). Proteins that did not bind to the column were subjected to gel filtration high-performance liquid chromatography using a TSK 250 column (Bio-Rad Laboratories Inc., Richmond, CA). Purified IgG was digested with pepsin (Worthington Biochemical Corp., Freehold, $\mathrm{NJ})$. Analysis of the IgG and $\mathrm{F}\left(\mathrm{ab}^{\prime}\right)_{2}$ in the reduced state by SDSPAGE and staining of the gels with Coomassie Blue revealed only polypeptides of apparent molecular weights of 50,000 and 25,000 30,000 for IgG and 25,000 for $F\left(a b^{\prime}\right)_{2}$.

Radioimmunoassay for antibodies specific for CR1. Replicate wells of flexible polyvinyl chloride U-bottom microtiter plates (Dynatech Laboratories, Inc., Alexandria, VA) were incubated overnight at $4^{\circ} \mathrm{C}$ with $250 \mathrm{ng}$ of purified CR1 in $0.025 \mathrm{ml}$ HBSS containing $1 \mathrm{mM}$ magnesium chloride, or with this buffer alone (33). The supernatants were removed and the wells were washed three times and incubated for $1 \mathrm{~h}$ at room temperature with HBSS containing $10 \mathrm{mg} / \mathrm{ml}$ BSA (HBSS-1\% BSA) to block nonspecific protein binding sites. Wells prepared in this manner were shown to be able to bind specifically ${ }^{125} \mathrm{I}-\mathrm{Yz}-1$ monoclonal anti-CR1. Dilutions of human serum, purified IgG, or its $\mathrm{F}\left(\mathrm{ab}^{\prime}\right)_{2}$ fragment in $0.025 \mathrm{ml} \mathrm{HBSS}-1 \%$ BSA containing 10 mM EDTA were added to CR1-coated wells and incubated for $1 \mathrm{~h}$ at room temperature. The supernatants were removed, the wells were washed three times with HBSS-1\% BSA, and the amount of immunoglobulin that had bound was determined by incubation of the wells for $1 \mathrm{~h}$ at room temperature with a saturating concentration of ${ }^{125} \mathrm{I}$ goat IgG antihuman $F\left(a^{\prime}\right)_{2}$. The developing antibody was removed, and the wells were washed, cut out, and assessed for radioactivity. CR1-specific binding of human immunoglobulin was calculated by subtraction of the amount of ${ }^{125} \mathrm{I}$-goat IgG antihuman $\mathrm{F}\left(\mathrm{ab}^{\prime}\right)_{2}$ bound to wells that had not been coated with CR1 from the amount of developing antibody that was bound to CR1-coated wells. Retrospective analyses of serum concentrations of autoantibody to CR1 used serum that had been maintained at $-70^{\circ} \mathrm{C}$

Clinical assays. Total hemolytic complement (34), C3 (35), C4 (35), immune complexes (36), and antinuclear antibodies (ANA) were assayed as described (37). The presence of precipitating antibodies to dsDNA, single-stranded DNA, NP, CTN, Sm, RNP, Ro, and La was assessed by counterimmunoelectrophoresis (37). HLA (38) and C4 (39) haplotypes were determined as described.

Case report. Patient $\mathrm{R}$ is a 29-yr-old caucasian woman with SLE. At age 24 she was noted to have a positive ANA during hospitalization after a spontaneous abortion. She subsequently developed butterfly rash, macular rash over her chest, patchy alopecia, wrist synovitis, lymph node enlargement, and splenomegaly. In 1980 the ANA titer was 1:640, total hemolytic complement was $108 \mathrm{U}$ (normal range, 150-250 U), and the serum immune complex concentration was $2,500 \mu \mathrm{g} / \mathrm{ml}$ (normal, $<23 \mu \mathrm{g} / \mathrm{ml}$ ). Subsequent analyses revealed the presence of antibodies to CTN, Sm, and RNP, but not to double- or single-stranded DNA, Ro, or La. The patient's HLA and C4 haplotypes were determined to be A1,B7,DR2,C4A3,C4B1/A11,Bx,Cw3,DR4, C4A4,C4B2. In October 1981, the binding of ${ }^{125}$ I-dimeric C3b to her E showed 173 sites/cell. She improved clinically in response to hydroxychloroquine and remained relatively well until May 1983, when she developed pleurisy and proteinuria. She improved in response to prednisone which was tapered during $7 \mathrm{mo}$ and discontinued in January 1984. On 13 February 1984, she had increased severity of rash and anemia, and recurrence of proteinuria. On this date, she was found to have no detectable CR1 on her E as assayed by the binding of ${ }^{125} \mathrm{I}-\mathrm{Yz}-1$. 


\section{Results}

Analysis of the CRI deficiency on cells of patient $R$. The number of antigenic sites on $E$ taken from patient $R$ on 29 February 1984 was determined by assay of the binding to these cells of ${ }^{125} \mathrm{I}-\mathrm{Yz}-1$, a monoclonal antibody directed to $\mathrm{CR} 1$, and of polyclonal ${ }^{125} \mathrm{I}-\mathrm{RaCR} 1$. There was no specific binding of either antibody to $E$ from patient $R$ (Fig. 1). Scatchard analysis of the equilibrium binding studies performed in parallel with cells from a healthy donor revealed 533 sites/ $E$ and 2,775 sites/E for the monoclonal and polyclonal antiCR1 antibodies, respectively. When these antibodies had been used in previous analyses of E from 164 patients with SLE and 213 healthy donors in the United States and France (13, 40, 41), the analyses had failed to identify another individual whose E were wholly lacking CR1.

When the number of CRI on E of patient R's first-degree relatives was determined, the mother, father, brother, and sister were found to have $694,738,902$, and 670 sites/E, respectively, for binding of $\mathrm{Yz}-1$. For comparison, 50 unrelated healthy donors were shown to have an average of $550 \pm 243$ (mean \pm SD) Yz-1 binding sites/E.

The inability to detect $C R 1$ on the patient's $E$ could have been caused by masking or internalization of the receptors. Therefore, membrane proteins of $1 \times 10^{10} \mathrm{E}$ from patient $\mathrm{R}$ and from a healthy donor, whose intact $E$ expressed $900{ }^{125} \mathrm{I}-$ Yz-1 binding sites/cell, were subjected to SDS-PAGE, transfer to nitrocellulose paper and immunoblotting with ${ }^{125} \mathrm{I}-\mathrm{Yz}-1$, and then autoradiography. CR1 in the $E$ lysate from the healthy donor was clearly demonstrated, but the receptor was not detectable in the lysate of $E$ from patient $R$ (Fig. 2). Additional low molecular weight bands that were present in the E lysates of both donors were also observed when ${ }^{125} \mathrm{I}$ 3G8, a monoclonal anti-Fc receptor antibody, was used to develop immunoblots of $\mathrm{E}$, and these bands probably represent nonspecific binding of the developing antibody to bands 4.2, 5 , and 6 , as described by others (42).

To assess whether cells other than $\mathrm{E}$ also were deficient in

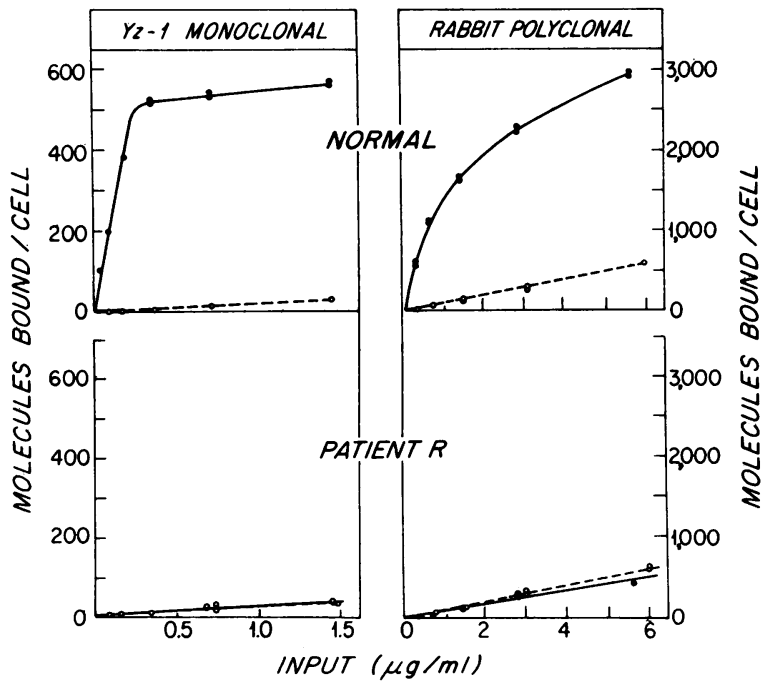

Figure 1. The binding of ${ }^{125} \mathrm{I}-\mathrm{Yz}-1$ murine monoclonal anti-CR 1 and rabbit ${ }^{125} \mathrm{I}-\mathrm{F}\left(\mathrm{ab}^{\prime}\right)_{2}$ anti-CR1 in the absence $(\bullet)$ and presence $(0)$ of excess unlabeled antibodies to $\mathrm{E}$ from a normal individual and from patient $\mathbf{R}$.

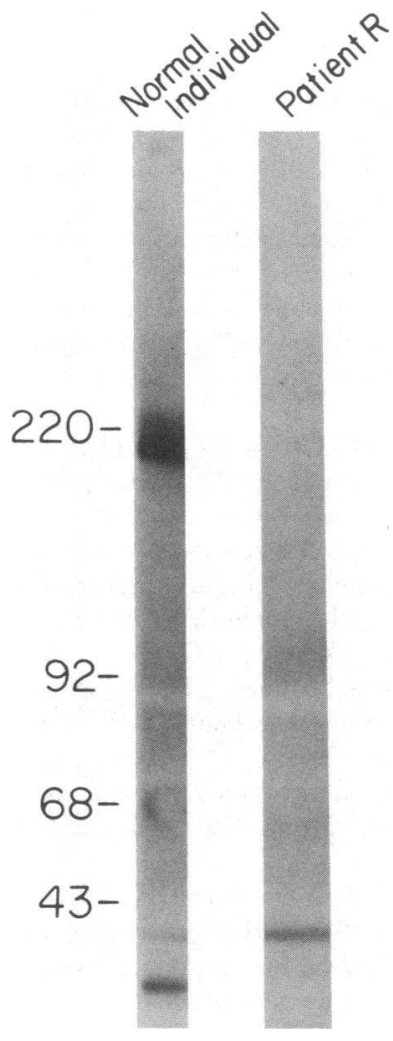

Figure 2. Analysis by immunoblotting of $\mathrm{E}$ membranes for the presence of CR1 antigen. Detergent lysates of $\mathrm{E}$ membranes from patient $R$ and a normal individual were subjected to SDS-PAGE under nonreducing conditions and transferred to nitrocellulose strips, which were probed with ${ }^{125} \mathrm{I}-\mathrm{Yz}-1$. The positions of the reduced protein standards of spectrin band 1 (220 kD), phosphorylase b (92 $\mathrm{kD})$, BSA (68 kD), and ovalbumin (43 kD) are shown.

CR1, the mononuclear leukocytes from patient $R$ on 19 March 1984 and cells from a healthy donor were stained with B1biotin and XRITC-avidin, and with RaCR1 and FITC-GaR, and analyzed by two-color immunofluorescent flow cytometry (Fig. 3). 9\% of the lymphocytes of the healthy donor and $17 \%$ of those of patient $R$ were identified as $B$ cells by their red fluorescence, and the respective mean channels of fluorescence were 50.1 and 53.1. The relative amount of CR1 on the B1positive cells, expressed as the mean channel of green fluorescence, was 38.1 for the healthy donor and 5.3 for patient $\mathbf{R}$. Replicate samples of lymphocytes stained nonspecifically with nonimmune rabbit $\mathrm{F}\left(\mathrm{ab}^{\prime}\right)_{2}$ and FITC-GaR exhibited mean channels of green fluorescence of 1.7 and 2.3, respectively. The mean fluorescent channel for CR1 staining of B1-positive lymphocytes was $35.2 \pm 7.4$ (mean $\pm \mathrm{SD}$; range, 26.6-43.9) for five other healthy donors.

CR1 of neutrophils was measured in detergent lysates of these cells by a sandwich radioimmunoassay, rather than on intact cells by flow cytometry, because most of this receptor resides in an intracellular compartment inaccessible to antibody $(43,44)$. On 19 March 1984, neutrophils from patient $R$ had 18,793 receptors/cell, which was less than half of the $43,297 \pm 7,674$ (mean \pm SD) receptors/cell measured for nine healthy donors.

Measurement of autoantibody to CRI in serum of patient $R$. The unprecedented, complete absence of $C R 1$ from $E$ of this patient, the previous finding of $173 \mathrm{CR} 1 /$ cell on her $\mathrm{E}$, and the relatively high numbers of receptors on $E$ of her firstdegree relatives suggested that a unique mechanism may have caused the acquired deficiency of CR 1 on her peripheral blood cells. Because patients with SLE may produce autoantibodies that are reactive with cell surface constituents, an assay was 

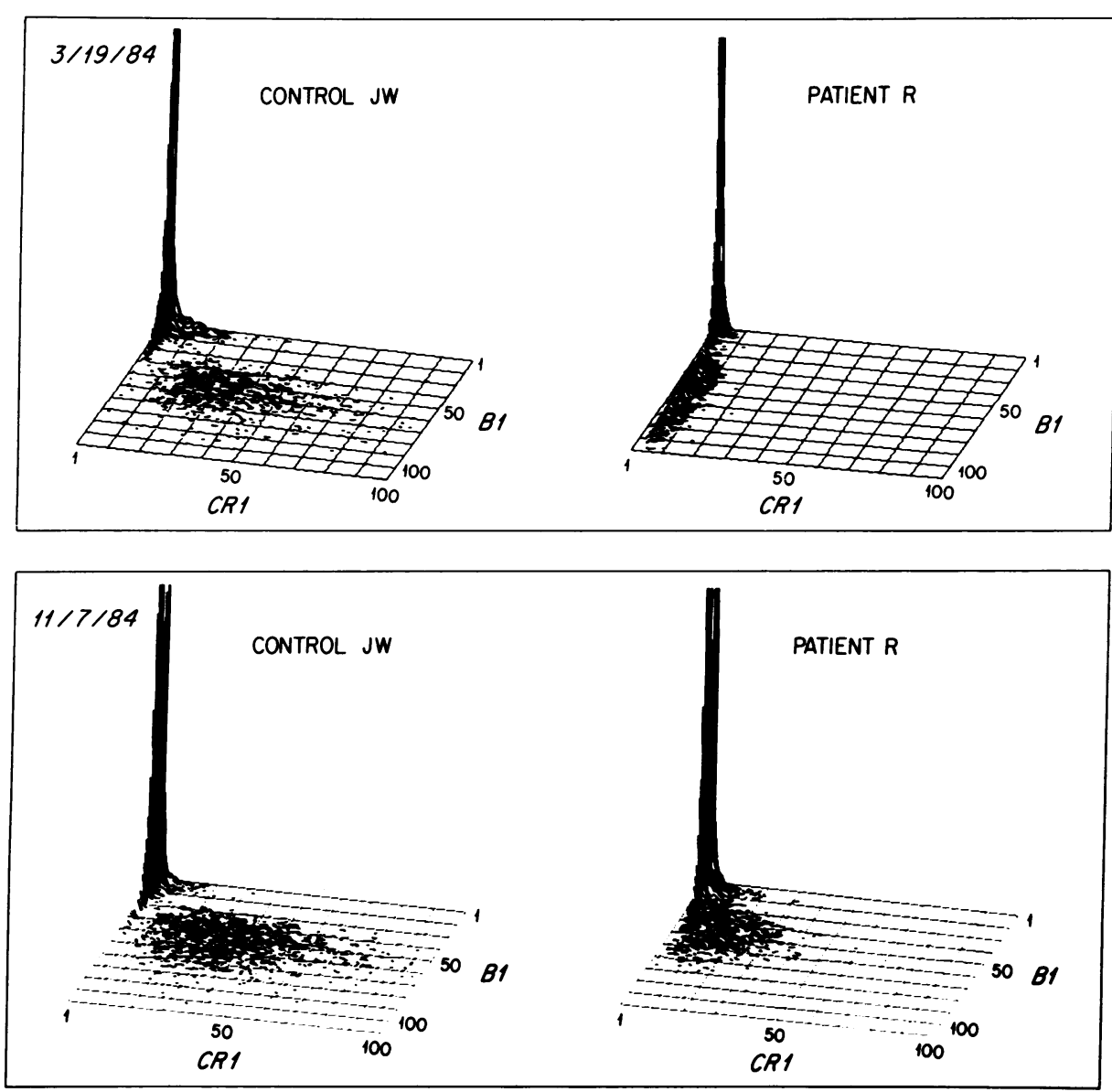

Figure 3. Isometric display of the distribution of peripheral blood lymphocytes according to their fluorescence intensity, as assessed by two-color cytofluorography, after indirect staining with XRITC-B1 and FITC-anti-CR1. The analyses of lymphocytes taken from patient $\mathrm{R}$ and the normal control, JW, on 19 March 1984 and 7 November 1984 are shown. developed to detect autoantibodies to CR1 in the serum of patient $R$. CRI was purified and analysis by SDS-PAGE showed the preparation to contain only the two major allotypic forms of the receptor (Fig. 4) $(45,46)$. Replicate samples of IgG purified from the serum obtained from patient $R$ on 1 May 1984 were incubated in microtiter wells that had been prepared with the purified CR1 or buffer alone. The wells were washed, incubated with ${ }^{125} \mathrm{I}$-goat IgG antihuman $\mathrm{F}\left(\mathrm{ab}^{\prime}\right)_{2}$, and assessed for the amount of detecting antibody that was bound. At each concentration of the patient's IgG there was greater binding of immunoglobulin to the CR1-coated wells than to the buffer-treated wells, with the highest concentration of IgG resulting in the specific binding of $\sim 8 \mathrm{ng}$ of the detecting antibody (Fig. 5).

A portion of the IgG and of purified C3 were subjected to digestion with pepsin. The $\mathrm{C} 3$ was degraded to peptides that migrated with the buffer front on 3 to $10 \%$ SDS-PAGE. The $\mathrm{F}\left(\mathrm{ab}^{\prime}\right)_{2}$ fragment was shown to bind specifically to CR1-coated microtiter wells (Fig. 5), indicating that the binding of the patient's immunoglobulin to CR1 was mediated by the $F\left(a b^{\prime}\right)_{2}$ region of the molecule and not by $\mathrm{C} 3$ fragments that may have been bound to the immunoglobulin.

To obtain additional evidence that the binding of the patient's immunoglobulin to CR1-coated wells was due to specific interaction with the antigen, the capacity of RaCR 1 to inhibit this interaction was assessed. Wells that had been prepared with CR1 or buffer alone were preincubated with either nonimmune rabbit $\mathrm{F}\left(\mathrm{ab}^{\prime}\right)_{2}$ or $\mathrm{RaCR} 1$ and washed, and the CR1-specific binding of the patient's purified IgG that had been preabsorbed against rabbit $\mathrm{F}\left(\mathrm{ab}^{\prime}\right)_{2}$-Sepharose, and of ${ }^{125} \mathrm{I}$ Yz-1, was measured. In four separate experiments, the specific binding of the patient's IgG to microtiter wells pretreated with RaCR 1 was $32 \pm 9.6 \%$ of the specific binding to wells pretreated with nonimmune $\mathrm{F}\left(\mathrm{ab}^{\prime}\right)_{2}$. Inhibition of the CR1-specific binding of ${ }^{125} \mathrm{I}-\mathrm{Yz}-1$ by $\mathrm{RaCR} 1$ was at least $95 \%$ in each experiment.

The anti-CR 1 present in serum obtained from patient $R$ on 29 May 1984 was characterized using ${ }^{125} \mathrm{I}$-labeled, isotypespecific goat antihuman immunoglobulin preparations as the developing antibodies in the microtiter assay. Immunoglobulin in the patient's serum that bound specifically to CR1-coated plates contained $\operatorname{IgG}$, IgA, and $\operatorname{IgM}$, but not $\operatorname{IgD}$, and both $\kappa$ and $\lambda$-light chains.

The capacity of purified IgG from patient $R$ to bind to $\mathrm{CR} 1$ in a plasma membrane was assessed indirectly by examining the inhibition of the binding of Yz-1. Replicate samples of $4 \times 10^{6}$ neutrophils in $0.1 \mathrm{ml}$ HBSS-BSA were preincubated for $60 \mathrm{~min}$ at $0^{\circ} \mathrm{C}$ with $1.2 \mathrm{mg}$ IgG purified from serum obtained from patient R on 1 May 1984, and from each of three healthy individuals. After being washed with ice-cold buffer, the cells were incubated with $5 \mu \mathrm{g} / \mathrm{ml} \mathrm{Yz-1}$ in HBSSBSA for $30 \mathrm{~min}$ at $0^{\circ} \mathrm{C}$, washed, stained by incubation with FITC-GaM for $30 \mathrm{~min}$ at $0^{\circ} \mathrm{C}$, and analyzed by cytofluorography. In two separate experiments, IgG from patient $\mathbf{R}$ inhibited the binding of Yz-1 to neutrophils by 46 and 35\%, whereas the IgG purified from the serum of the healthy donors reduced Yz-1 binding by only 0 to $11 \%$ (Table I). 


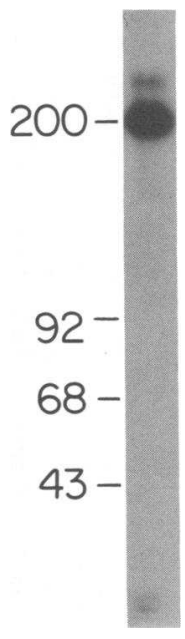

Figure 4. Analysis by SDS-PAGE and autoradiography of purified CR1 that had been labeled with ${ }^{125}$ I. Numbers to left of gel are molecular weights in thousands.

The ability of serum from patient $R$ to inhibit $C R 1$ function was examined by incubating replicate samples of $2.5 \times 10^{8}$ normal $\mathrm{E}$ in $0.05 \mathrm{ml}$ of either HBSS-BSA, serum from a healthy donor, or serum obtained from the patient on 29 February or 1 May 1984 . After $60 \mathrm{~min}$ at $0^{\circ} \mathrm{C}$, the cells were washed with ice-cold HBSS-BSA, resuspended in this buffer containing $20 \mu \mathrm{g} / \mathrm{ml}$ goat IgG anti-human $\mathrm{F}\left(\mathrm{ab}^{\prime}\right)_{2}$, and incubation was continued for $60 \mathrm{~min}$ more at $0^{\circ} \mathrm{C}$. After they were washed the cells were assessed for their capacity to bind ${ }^{125}$ I-dimeric C3b. E that had been pretreated with buffer or with normal serum bound 143 and $130 \mathrm{C} 3 \mathrm{~b}$ molecules/cell, respectively. In contrast, pretreatment of the cells with the two serum samples taken from patient $\mathbf{R}$ decreased the binding to 69 and $54 \mathrm{C} 3 \mathrm{~b}$ molecules/cell, representing 45 and $52 \%$ inhibition, respectively. In a separate experiment, sequential pretreatment of normal $E$ with plasma taken from patient $R$ on 29 February 1984 and with goat $\operatorname{IgG}$ antihuman $\mathrm{F}\left(\mathrm{ab}^{\prime}\right)_{2}$ caused $37 \%$ inhibition of subsequent ${ }^{125} \mathrm{I}$-dimeric $\mathrm{C} 3 \mathrm{~b}$ binding relative to the uptake observed with buffer-treated cells. No inhibition occurred with $\mathrm{E}$ pretreated only with patient plasma but not with antihuman $\mathrm{F}\left(\mathrm{ab}^{\prime}\right)_{2}$.

28 healthy donors, 34 additional patients who fulfilled the revised criteria for the diagnosis of SLE (47), and the four first-degree relatives of patient $R$ were compared with patient $\mathbf{R}$ for the presence of anti-CR 1 in their undiluted sera containing $10 \mathrm{mM}$ EDTA. The CR1-specific binding of serum immunoglobulin was $1.3 \pm 0.5 \mathrm{ng} /$ well (mean \pm SEM) of ${ }^{125} \mathrm{I}$-goat IgG antihuman $\mathrm{F}\left(\mathrm{ab}^{\prime}\right)_{2}$ for the healthy donors, $2.8 \pm 1.3 \mathrm{ng} /$ well for the family members of patient $R$, and $0.5 \pm 0.3 \mathrm{ng} /$ well for individuals with SLE, none of whose sera exhibited anti-CR 1 activity that approached the amount, $19.1 \mathrm{ng} /$ well, observed with serum taken from patient $R$ on 29 May 1984 (Fig. 6). The four normal individuals with the most immunoglobulin binding to CR1-coated plates had CR1/E ranging from 475 to 688. Their antibodies to $\mathrm{CR} 1$ may have been directed to cryptic regions of the receptor that are not expressed in its native form, as is the case with autoantibodies in normal individuals to band 3 (42).

Temporal relationship between cellular $C R 1$, serum anti$C R 1$, and activity of disease. On 13 February 1984, when the patient was first noted to lack $\mathrm{CR} 1$ on $\mathrm{E}$, prednisone was reinstituted at a dose of $20 \mathrm{mg} / \mathrm{d}$ because of rash, anemia, and

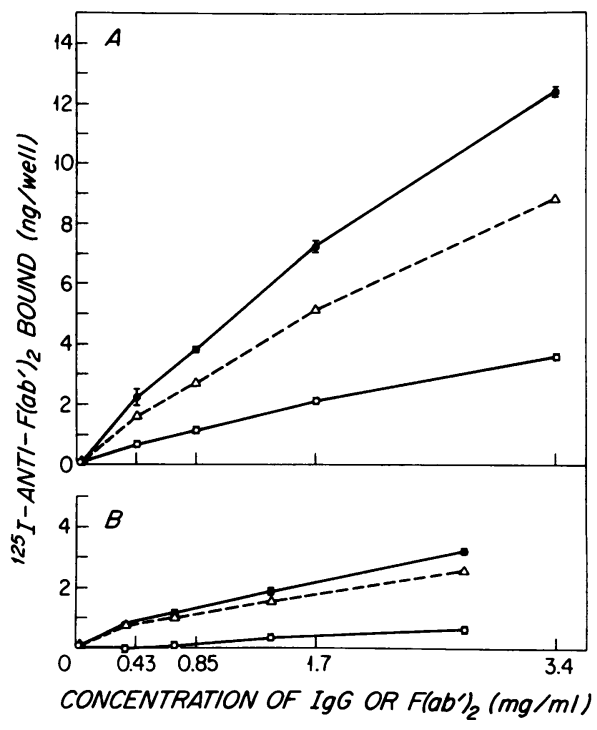

Figure 5. The binding of purified IgG from patient $\mathrm{R}(A)$ and its $\mathrm{F}\left(\mathrm{ab}^{\prime}\right)_{2}$ fragment $(B)$ to $\mathrm{CR} 1$-coated microtiter wells. IgG or $\mathrm{F}\left(\mathrm{ab}^{\prime}\right)_{2}$ was incubated in microtiter wells that had been pretreated with purified CR1 (•) or with buffer (o), the wells were washed, and bound Ig was detected by subsequent incubation of the well with ${ }^{125} \mathrm{I}$ labeled goat IgG antihuman $F\left(a b^{\prime}\right)_{2}$. CR1-specific binding of the human IgG and $F\left(a b^{\prime}\right)_{2}(\Delta)$ was calculated by subtracting the binding to wells that had been pretreated with buffer from that to wells coated with CR1.

recurrence of proteinuria (Fig. 7). The dose of prednisone was eventually increased to $90 \mathrm{mg} / \mathrm{d}$ in June because of persistent disease activity with increased anemia and positive Coombs' test. The patient then improved and prednisone was decreased.

Anti-CR 1 activity was measured by the radioimmunoassay in serum samples that had been obtained from patient $R$ since her initial visit to the Brigham and Women's Hospital in November 1980. The serum concentration of anti-CR 1 was relatively low during the initial two and one-half years that followed the onset of SLE, even during the periods of heightened disease activity in November 1980, and May 1983. In September 1983, patient R's serum had the highest concentration of

Table I. Inhibition of the Binding of Yz-1 to Neutrophils by Preincubation of the Neutrophils with Human IgG*

\begin{tabular}{llll}
\hline & & \multicolumn{2}{c}{ Percent inhibition } \\
\cline { 3 - 4 } & of IgG & Experiment 1 & Experiment 2 \\
\hline Normal donors & 1 & 0 & 1 \\
& 2 & 3 & 5 \\
Patient R & 3 & 11 & 9 \\
& & 46 & 35
\end{tabular}

* Binding of Yz-1 was assessed by subsequent staining with FITCGaM and immunofluorescent flow cytometry. Percent inhibition $=[1-$ (mean fluorescent channel of neutrophils preincubated with patient or control $\mathrm{IgG} /$ mean fluorescent channel of neutrophils incubated in buffer alone)] $\times 100$. 
anti-CR 1 observed during her clinical course. The anti-CR 1 concentration had decreased four- to fivefold before the institution of high-dose prednisone therapy in June 1983, after which the antibody concentration decreased to the level observed before 1983 .

After October 1981, when the number of CR1/E had been 173 , as determined by the binding of ${ }^{125} \mathrm{I}$-labeled dimeric $\mathrm{C} 3 \mathrm{~b}$, patient R's E were not examined again until February 1984, when she was twice found to have no antigenically detectable CR1 sites. CR1 number remained at $\sim 10$ sites/cell through June. By August this number had returned to 170 sites/cell, coincident with the decrease in the serum anti-CR1 concentration. Repeat measurement of neutrophil CR1 on 7 November 1984 showed 35,364 molecules/cell, twice the amount present on 19 March 1984. Reanalysis of CR1 on B lymphocytes on 7 November by fluorescent flow cytometry revealed that the mean fluorescent channel had increased to 16.8 , which, however, was less than the level of 41.2 observed with stained B cells of the normal individual assayed at the same time (Fig. 3).

Serum concentration of C4 antigen (normal, $26-83 \mathrm{mg}$ / dl) was $13 \mathrm{mg} / \mathrm{dl}$ when patient $R$ presented in 1980 , was in the normal range in May 1982, decreased to $21 \mathrm{mg} / \mathrm{dl}$ in 1983 and to $18 \mathrm{mg} / \mathrm{dl}$ in 1984 during the two episodes of increased clinical activity of disease, and returned to normal in June 1984. C3 concentration was normal throughout the clinical course. The serum immune complex concentration was 400 $500 \mu \mathrm{g} / \mathrm{ml}$ throughout $1983,820 \mu \mathrm{g} / \mathrm{ml}$ on 13 February 1984 , fell to $<20 \mu \mathrm{g} / \mathrm{ml}$ by 19 March 1984 , and remained in this range. The hematocrit fell to $25 \%$ in May 1984 and rose to $37 \%$ by August 1984. The episode of anemia was accompanied by positive Coombs' test but not by reticulocytosis or decreased serum haptoglobin. Furthermore, $E$ taken from patient $R$ in February 1984, which were totally lacking CR1, did not exhibit increased lysis in Ham's test.

\section{Discussion}

A total of 300 patients with SLE and 514 normal individuals have been assessed by investigators in Japan, North America, and Europe $(12,13,15,16,40,41)$ for the number of antigenically detectable CR1 on their E, and before this report, none had been found to have a complete absence of this receptor. The conclusion that $E$ from patient $R$ in early 1984 lacked CR1 was based on there being no specific binding to her cells of either monoclonal or polyclonal anti-CR1 (Fig. 1) and on the absence of detectable CRI antigen on transblots of

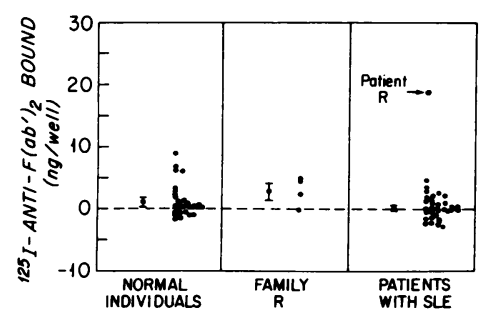

Figure 6. The amount of immunoglobulin in undiluted serum that reacted specifically with $\mathrm{CR} 1$ in microtiter wells, as determined by the binding of ${ }^{125} \mathrm{I}-\mathrm{goat} \mathrm{IgG}$ anti-F $\left(\mathrm{ab}^{\prime}\right)_{2}$, among 28 normal individuals, 4 first-degree relatives of patient $R, 34$ patients with SLE, and patient $R$.

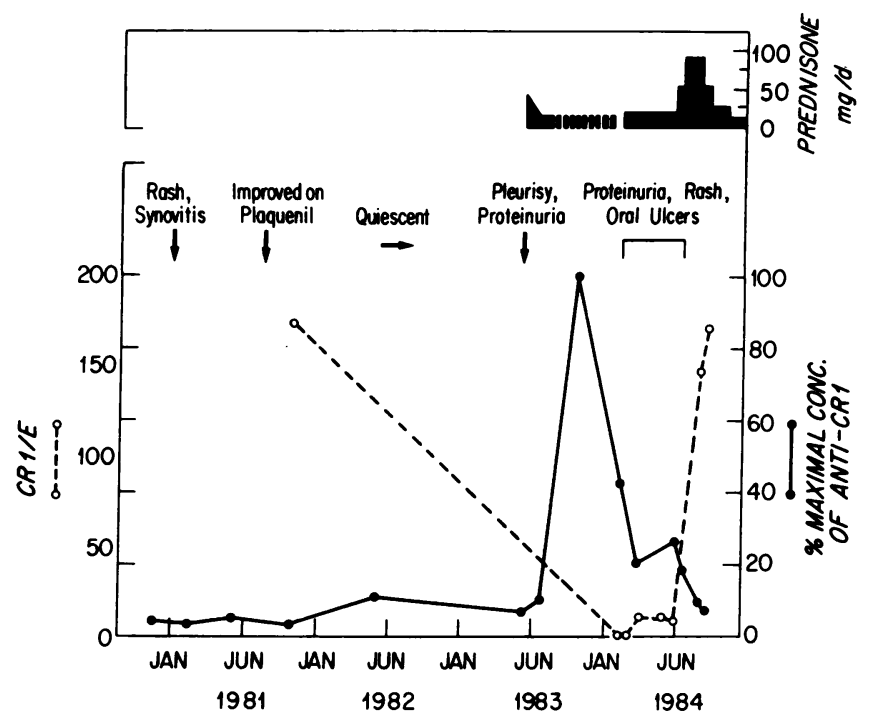

Figure 7. The number of $\mathrm{CR} 1$ sites/E (O) and the serum concentration (Conc.) of anti-CR1 (•) of patient R during 1981-1984.

E membranes (Fig. 2). Therefore, it seemed likely that a process distinct from inheritance $(13,16)$ or complement activation (15) accounted for this unique abnormality, and an autoantibody to the receptor was sought in this patient. A radioimmunoassay was developed using CR1-coated microtiter wells that was sensitive, specific, and quantitative. With a specific radioactivity of revealing antibody of $10^{6} \mathrm{cpm} / \mu \mathrm{g}$, and assuming a 1:1 stoichiometry for the interaction of human Ig with the radiolabeled goat antihuman $F\left(a b^{\prime}\right)_{2}$, the specific binding of as little as $0.2 \mathrm{ng}$ of IgG autoantibody in $0.025 \mathrm{ml}$ of serum, or $0.0001 \%$ of the serum concentration of IgG, could be detected. The specificity of the assay, although addressed in part by the use of a CR1 antigen that had been purified to homogeneity as assessed by SDS-PAGE (Fig. 4), was further assured by the demonstration that monospecific, polyclonal RaCR 1 inhibited by $68 \%$ the binding of patient R's IgG to antigen-coated wells. The noninhibitable binding of the IgG could have been to epitopes not recognized by the rabbit antibody, such as those expressed in denatured CR1 to which this antibody does not bind. The finding that both purified IgG and its $F\left(a^{\prime}\right)_{2}$ fragment bound to the CR1-coated wells (Fig. 5) excluded the possibility that the assay was merely detecting C3-bearing immune complexes, especially when considered with the observation of the marked sensitivity of $\mathrm{C} 3$ to pepsin. The quantitative decrease in the binding of the $\mathrm{F}\left(\mathrm{ab}^{\prime}\right)_{2}$ fragment as compared with that of IgG (Fig. 5) apparently was due to partial denaturation of the autoantibody under the conditions of the pepsin digestion. IgG incubated under identical conditions but in the absence of pepsin showed a reduction in binding to CR1 of $\sim 50 \%$ as compared with that of IgG that had been held on ice. The quantitative nature of the radioimmunoassay, as demonstrated in the assay depicted in Fig. 5, was essential for the comparison of patient R's serum with that of other SLE patients and normal individuals (Fig. 6) and for the analysis of the relationship between the autoantibody and her clinical course (Fig. 7).

Antigenic analysis of the constant regions of the autoanti- 
body demonstrated that the anti-CR1 was included among the major classes of antibody in serum and that both $\kappa$ - and $\lambda$ light chains were present, indicating that it was polyclonal. The specificity of patient R's autoantibody included epitopes expressed by native $C R 1$ present in the plasma membrane of E and neutrophils (Table I), as indirectly indicated by the capacity of serum and purified IgG to inhibit binding of dimeric $\mathrm{C} 3 \mathrm{~b}$ and $\mathrm{Yz}-1$ to these cells, respectively. The requirement of a second, anti-human antibody for inhibition of dimeric $\mathrm{C} 3 \mathrm{~b}$ binding suggests that the epitopes recognized by patient R's autoantibody did not include the ligand-binding site of the receptor.

B lymphocytes resembled $E$ in having almost no detectable CR1 (Fig. 3), whereas the CR1 content of neutrophils was $\sim 50 \%$ of normal. Although the difference between these cells in the severity of the CR1 deficiency may have been caused by the analysis of surface CRI of B cells and E and of total CR1 of neutrophils, it may also reflect the localization of most of CRI in circulating, nonactivated neutrophils to compartments inaccessible to extracellular ligands $(43,44)$. The mechanism by which interaction of autoantibody with CR1 causes loss of the receptor has not been addressed in this study, but it is unlikely to be wholly secondary to complement activation at the cell surface because comparable deficiencies of CR 1 have not been observed on $\mathrm{E}$ of patients with autoimmune hemolytic anemia (48).

The possibility that the receptor abnormality in patient $R$ was a consequence of the autoantibody is supported by the inverse relationship between these two measurements before, during, and after the period of the marked deficiency on $\mathrm{E}$ (Fig. 7). Furthermore, analysis of 34 other patients revealed no binding of immunoglobulin to CR1-coated plates in excess of that observed in serum from normal individuals (Fig. 6), and no SLE patient has previously been found to have absent CRI on E, which suggests a unique relationship between the presence of the autoantibody and the absence of CR1 in patient $R$. The autoantibody may also have been responsible for the CR1 deficiency of patient R's neutrophils and B lymphocytes, as there was improvement in these abnormalities after the decrease in serum concentration of anti-CR1 (Fig. 3). However, because there are no other quantitative data available about CR1 expression on leukocytes of patients with SLE, it is not possible to conclude that the leukocyte abnormality was unique to patient $R$. In addition, other pathophysiologic processes able to cause acquired $C R 1$ deficiency may have been occurring in patient $R$, since the level of $C R 1$ sites/E, 170 , observed at times of low anti-CR 1 concentration was lower than would have been predicted based on inheritance, as all of the patient's first-degree relatives had $>600 \mathrm{CR} 1 / \mathrm{E}$.

The possible biologic consequences of the autoantibody include the inability of the CR1-deficient E to clear immune complexes, and perhaps some impairment in the capacity of granulocytes to ingest $\mathrm{C} 3 \mathrm{~b}$-bearing particles, such as complement-opsonized bacteria. The effects on B lymphocytes of the autoantibody may have been either stimulatory or inhibitory, depending on whether cross-linking of receptors by the autoantibody directly elicited a biologic response, as has been demonstrated for the interaction of human $B$ cells with rabbit anti-CR 1 (49), or blocked the ability of the cell to respond to natural ligand by creating a CR1 deficiency.
Among diseases thought to be caused by the production of autoantibodies, SLE has been considered unusual in that the disease process depends more on formation of immune complexes that cause inflammatory tissue damage than on the particular biologic functions or tissue site of the antigen recognized by the autoantibody. In contrast, antigenic specificity is critical to the effects of the anti-receptor antibodies that are responsible for myasthenia gravis (50), Graves' disease (51), and diabetes mellitus associated with anti-insulin receptor antibodies (52). Therefore, the present finding in a patient with SLE of an autoantibody to CR 1 may provide an exception to this generalization because the biologic effects of this autoantibody could include impaired clearance of immune complexes and altered function of B lymphocytes. The inability to detect antibody of similar specificity in other patients with SLE may indicate either that patient $R$ is indeed unique qualitatively or that other patients are in antigen excess, making difficult the detection of free antibody.

\section{Acknowledgments}

We thank Dr. Edmund Yunis, in whose laboratory HLA typing was performed, and Dr. Chester Alper, whose laboratory performed C4 allotyping.

This work was supported by grants AI-07722, AI-10356, AM32705, AI-19397, AM-05577, AM-11414, AI-17917, AM-20580, RR01996, and RR-05669 from the National Institutes of Health, and in part by a grant from the New England Peabody Home for Crippled Children and the Lupus Foundation of America. Dr. Wong is a fellow of the National Arthritis Foundation.

\section{References}

1. Tan, E. M. 1982. Autoantibodies to nuclear antigens (ANA): their immunobiology and medicine. Adv. Immunol. 33:167-240.

2. Senecal, J. L., N. F. Rothfield, and J. M. Oliver. 1982. Immunoglobulin $\mathrm{M}$ autoantibody to vimentin intermediate filaments. $J$. Clin. Invest. 69:716-721.

3. Alcover, A., J. Molano, J. Renart, A. Gil-Aguado, A. Nieto, and J. Avila. 1984. Antibodies to vimentin intermediate filaments in sera from patients with systemic lupus erythematosus. Arthritis Rheum. 27: 922-928.

4. Okudaira, K., R. P. Searles, J. L. Ceuppens, J. S. Goodwin, and R. C. Williams, Jr. 1982. Anti-Ia reactivity in sera from patients with systemic lupus erythematosus. J. Clin. Invest. 69:17-24.

5. Ooi, B. S., Y. M. Ooi, A. J. Pesce, and V. E. Pollak. 1977. Antibodies to $\beta_{2}$ microglobulin in the sera of patients with systemic lupus erythematosus. Immunology. 33:535-541.

6. Hirano, T., H. Hashimoto, Y. Shiokawa, M. Iwamori, Y. Nagai, M. Kasai, Y. Ochiai, and K. Okumura. 1980. Antiglycolipid autoantibody detected in the sera from systemic lupus erythematosus patients. J. Clin. Invest. 66:1437-1440.

7. Halbwachs, L., M. Leveillé, P. H. Lesavre, S. Wattel, and J. Leibowitch. 1980. Nephritic factor of the classical pathway of complement. Immunoglobulin $\mathbf{G}$ autoantibody directed against the classical C3 pathway convertase enzyme. J. Clin. Invest. 65:1249-1256.

8. Daha, M. R., H. M. Hazevoet, L. A. van Es, and A. Cats. 1980. Stabilization of the classical pathway $\mathrm{C} 3$ convertase $\mathrm{C} 42$, by a factor $\mathrm{F}-42$, isolated from serum of patients with systemic lupus erythematosus. Immunology. 40:417-424. 
9. Gigli, 1., J. Sorvillo, L. Mecarelli-Halbwachs, and Jacques Leibowitch. 1981. Mechanism of action of the C4 nephritic factor. $J$. Exp. Med. 154:1-12.

10. Koffler, D., P. H. Schur, and H. G. Kunkel. 1967. Immunological studies concerning the nephritis of systemic lupus erythematosus. $J$. Exp. Med. 126:607-624.

11. Miyakawa, Y., A. Yamada, K. Kosaka, F. Tsuda, E. Kosuga, and M. Mayumi. 1981. Defective immune adherence (C3b) receptor on erythrocytes of patients with systemic lupus erythematosus. Lancet. II:493-497.

12. Iida, K., R. Mornaghi, and V. Nussenzweig. 1982. Complement receptor (CR1) deficiency in erythrocytes from patients with systemic lupus erythematosus. J. Exp. Med. 155:1427-1438.

13. Wilson, J. G., W. W. Wong, P. H. Schur, and D. T. Fearon. 1982. Mode of inheritance of decreased C3b receptors on erythrocytes of patients with systemic lupus erythematosus. N. Engl. J. Med. 307: 981-986.

14. Taylor, R. P., C. Horgan, R. Buschbacher, C. M. Brunner, C. E. Hess, W. M. O'Brien, and H. J. Wanebo. 1983. Decreased complement-mediated binding of antibody $/{ }^{3} \mathrm{H}$-dsDNA immune complexes of the red blood cells of patients with systemic lupus erythematosus, rheumatoid arthritis, and hematologic malignancies. Arthritis Rheum. 26:736-744.

15. Ross, G. D., M. J. Walport, C. J. Parker, A. J. Lentine, C. R. Fuller, W. J. Yount, B. L. Myones, J. B. Winfield, and P. J. Lachmann. 1984. Acquired loss of erythrocyte (E) CR1 (C3b-receptor) in systemic lupus erythematosus and other diseases with autoantibodies and/or complement activation. Arthritis Rheum. 27:S28. (Abstr.)

16. Minota, S., C. Terai, Y. Nojima, K. Takano, E. Takai, Y. Miyakawa, and F. Takaku. 1984. Low C3b receptor activity on erythrocytes from patients with systemic lupus erythematosus detected by immune adherence hemagglutination and radioimmunoassays with monoclonal antibody. Arthritis Rheum. 27:1329-1335.

17. Horgan, C., and R. P. Taylor. 1984. Studies on the kinetics of binding of complement-fixing dsDNA/anti-dsDNA immune complexes to the red blood cells of normal individuals and patients with systemic lupus erythematosus. Arthritis Rheum. 27:320-329.

18. Kazatchkine, M. D., D. T. Fearon, M. D. Appay, C. Mandet, and J. Bariety. 1982. Immunohistochemical study of the human glomerular C3b receptor in normal kidney and in seventy-five cases of renal diseases. J. Clin. Invest. 69:900-912.

19. Emancipator, S. N., K. Iida, V. Nussenzweig, and G. R. Gallo. 1983. Monoclonal antibodies to human complement receptor (CR1) detect defects in glomerular diseases. Clin. Immunol. Immunopathol. 27:170-175.

20. Cornacoff, J. B., L. A. Hebert, W. L. Smead, M. E. VanAman, D. J. Birmingham, and F. J. Waxman. 1983. Primate erythrocyte immune complex clearing mechanism. J. Clin. Invest. 71:236-247.

21. Fearon, D. T. 1980. Identification of the membrane glycoprotein that is the $\mathrm{C} 3 \mathrm{~b}$ receptor of the human erythrocyte, polymorphonuclear leukocyte, B lymphocyte and monocyte. J. Exp. Med. 152:20-30.

22. Fraker, P. J., and J. C. Speck. 1978. Protein and cell membrane iodinations with a sparingly soluble chloramide 1,3,4,6,-tetrachloro3a,6a-diphenylglycoluril. Biochem. Biophys. Res. Commun. 80:849857.

23. Changelian, P. S., R. M. Jack, L. A. Collins, and D. T. Fearon. 1985. PMA induces the ligand-independent internalization of $C R 1$ on human neutrophils. J. Immunol. 134:1851-1858.

24. Garvey, J. S., N. E. Cremer, and D. H. Sussdorf. 1977. Methods in Immunology. 3rd ed. The Benjamin-Cummings Publishing Co., Menlo Park, CA. 215-270.

25. Nadler, L. M., P. Stashenko, R. Hardy, A. van Agthoven, C. Terhorst, and S. F. Schlossman. 1981. Characterization of a human B cell-specific antigen (B2) distinct from B1. J. Immunol. 126:19411947.

26. Cook, J., E. Fischer, C. Boucheix, M. Mirsrahi, M-H. Jouvin, L. Weiss, R. M. Jack, and M. D. Kazatchkine. 1985. Mouse monoclonal antibodies to the human $\mathrm{C} 3 \mathrm{~b}$ receptor. Mol. Immunol. In press.

27. Fearon, D. T. 1979. Regulation of the amplification C3 convertase of human complement by an inhibitory protein isolated from the human erythrocyte membrane. Proc. Natl. Acad. Sci. USA. 76:5867-5871.

28. Laemmli, U. K. 1970. Cleavage of structural proteins during the assembly of the head of bacteriophage T4. Nature (Lond.). 227: 680-685.

29. Yoon, S. H., and D. T. Fearon. 1985. Characterization of a soluble form of the $\mathrm{C} 3 \mathrm{~b} / \mathrm{C} 4 \mathrm{~b}$ receptor $(\mathrm{CR} 1)$ in human plasma. $J$. Immunol. 134:3332-3338.

30. Towbin, H., T. Staehelin, and J. Gordon. 1979. Electrophoretic transfer of proteins from acrylamide gels to nitrocellulose sheets: procedure and some applications. Proc. Natl. Acad. Sci. USA. 76: $4350-4354$.

31. Boyum, A. 1968. Isolation of leukocytes from human blood: further observations. Scand. J. Clin. Lab. Invest. 21(Suppl. 97):31-50.

32. Unkeless, J. C., and G. A. Healy. 1983. Quantitation of proteins and internal antigen pools by a monoclonal antibody sandwich radioimmune assay. J. Immunol. Methods. 56:1-11.

33. Howard, F. D., J. A. Ledbetter, S. Q. Mehdi, and L. A. Herzenberg. 1980. A rapid method for the detection of antibodies to cell surface antigens: a solid phase radioimmunoassay using cell membranes. J. Immunol. Methods. 38:75-84.

34. Kent, J. F., and E. H. Fife, Jr. 1963. Precise standardization of reagents for complement fixation. Am. J. Trop. Med. 12:103-116.

35. Schur, P. H. 1977. Complement testing in the diagnosis of immune and autoimmune diseases. Am. J. Clin. Pathol. 68:647-659.

36. Kammer, G. M., N. A. Soter, and P. H. Schur. 1980. Circulating immune complexes in patients with necrotizing vasculitis. Clin. Immunol. Immunopathol. 15:658-672.

37. Schur, P. H. 1977. Detection and characterization of antibodies to nuclei, nuclear constituents, and nucleic acids by immunofluorescence and counterimmunoelectrophoresis. Ann. Rheum. Dis. 36:108-111.

38. Mittal, K. K., M. R. Mickey, D. P. Singal, and P. I. Terasaki. 1968. Serotyping for homotransplantation. Transplantation. 6:913927.

39. Awdeh, Z. L., and C. A. Alper. 1980. Inherited structural polymorphism of the fourth component of human complement. Proc. Natl. Acad. Sci. USA. 77:3576-3580.

40. Wilson, J. G., D. T. Fearon, and P. H. Schur. 1984. Correlation between erythrocyte $(\mathrm{E}) \mathrm{C} 3 \mathrm{~b}$ receptor $(\mathrm{C} 3 \mathrm{bR})$ number and antibody to double-stranded DNA (anti-dsDNA) in systemic lupus erythematosus (SLE). Arthritis Rheum. 27:S82 (Abstr.)

41. Wilson, J. G., M-H. Jouvin, M. D. Kazatchkine, and D. T. Fearon. 1984. Erythrocyte (E) CR1 in systemic lupus erythematosus (SLE). Complement. 1:167a. (Abstr.)

42. Lutz, H. U., R. Flepp, and G. Stringaro-Wipf. 1984. Naturally occurring autoantibodies to exoplasmic and cryptic regions of band 3 protein, the major integral membrane protein of human red blood cells. J. Immunol. 133:2610-2618.

43. Fearon, D. T., and L. A. Collins. 1983. Increased expression of $\mathrm{C} 3 \mathrm{~b}$ receptors on polymorphonuclear leukocytes induced by chemotactic factors and by purification procedures. J. Immunol. 130:370375.

44. Lee, J., R. M. Hakim, and D. T. Fearon. 1984. Increased expression of the $\mathrm{C} 3 \mathrm{~b}$ receptor by neutrophils and complement activation during haemodialysis. Clin. Exp. Immunol. 56:205-214. 
45. Dykman, T. R., J. L. Cole, K. Iida, and J. P. Atkinson. 1983. Polymorphism of the human erythrocyte $\mathrm{C} 3 \mathrm{~b} / \mathrm{C} 4 \mathrm{~b}$ receptor. Proc. Natl. Acad. Sci. USA. 80:1698-1702.

46. Wong, W. W., J. G. Wilson, and D. T. Fearon. 1983. Genetic regulation of a structural polymorphism of human $\mathrm{C} 3 \mathrm{~b}$ receptor. $J$. Clin. Invest. 72:685-693.

47. Tan, E. M., A. S. Cohen, J. F. Fries, A. T. Masi, D. J. McShane, N. F. Rothfield, J. G. Schaller, N. Talal, and R. J. Winchester. 1982. The 1982 revised criteria for the classification of systemic lupus erythematosus. Arthritis Rheum. 25:1271-1277.

48. Parker, C. J., C. M. Soldato, and M. J. Telen. 1984. Increased efficiency of binding of nascent $\mathrm{C} 3 \mathrm{~b}$ to the erythrocytes of chronic cold agglutinin disease. J. Clin. Invest. 74:1050-1062.
49. Daha, M. R., A. C. Bloem, and R. E. Ballieux. 1984. Immunoglobulin production by human peripheral lymphocytes induced by anti-C3 receptor antibodies. J. Immunol. 132:1197-1201.

50. Almon, R. R., C. G. Andrew, and S. H. Appel. 1974. Serum globulin in myasthenia gravis: inhibition of $\alpha$-bungarotoxin binding to acetylcholine receptors. Science (Wash. DC). 186:55-57.

51. Smith, B. R., and R. Hall. 1974. Thyroid-stimulating immunoglobulins in Graves' disease. Lancet. II:427-431.

52. Flier, J. S., C. R. Kahn, and J. Roth. 1979. Receptors, antireceptor antibodies and mechanisms of insulin resistance. $N$. Engl. J. Med. 300:413-419. 